Page 133-148

\title{
MUDHARABAH AGRI-CROWDFUNDING IN THE EX-CLAY MINE UTILIZATION PROGRAM OF PT. SEMEN INDONESIA (PERSERO), TBK. CAMPUS OF C UNIVERSITAS INTERNASIONAL SEMEN INDONESIA
}

\author{
Bambang Tutuko $^{1}$, Ahmad Hudaifah*2, M. Asyhad ${ }^{3}$, Paramita Setyaningrum ${ }^{4}$, \\ Irvan Adhin Cholilie ${ }^{5}$ \\ ${ }^{1,2}$ Sharia Economic Department, Faculty of Economic and Business \\ Universitas Internasional Semen Indonesia \\ Kompleks PT. Semen Indonesia (Persero) Tbk, Jl. Veteran, Kb. Dalem, Sidomoro, \\ Kebomas, Gresik, Indonesia \\ bambangtutuko@uisi.ac.id \\ ahmadhudaifah@uisi.ac.id \\ 3.4.5Agroindustrial Technology Department, Faculty of Industrial Technology and \\ Agroindustry, Universitas Internasional Semen Indonesia \\ Kompleks PT. Semen Indonesia (Persero) Tbk, Jl. Veteran, Kb. Dalem, Sidomoro, \\ Kebomas, Gresik, Indonesia \\ m.asyhad@uisi.ac.id \\ paramitasetyaningrum@uisi.ac.id \\ irvanadhincholilie@uisi.ac.id
}

\begin{abstract}
The objectives of research are to study market, technical, and financial feasibility of crowdfunding project using Syariah contract on specified agriculture project based on a higher education institute potency. Such process will be carried out to identify a feasibility of the land use in the project and the amount of funding needed to be collected with the concept of crowdfunding. The construction of a project requires analysis to determine the feasibility of the project. Method of research is quantitative by calculating financial feasibility. UISI has a land area of 3.8 hectares located on Campus of C UISI. This land is an ex-clay mining land of Semen Indonesia Company. Total investment and capital funding amount to $\mathrm{Rp}$ 100,000,000. The investment return period is 2 years. Based on the profit and loss calculation, it can be considered that capital and investment will return in the 6th month of the 1st year. In the 1st year the IRR obtained was 19\%, whereas until the end of the second year the IRR was obtained by $42 \%$. A significant difference occurred because in the second year Belimbing Tasikmadu, and Jambu Kristal fruit could already be harvested for commercial purpose.
\end{abstract}

Keywords: Ex-Clay Mining; Financial Feasibility; Internal Rate Of Return; Net Present Value

Received: March 12, 2019; Accepted: July 09, 2019; Published: July 16, 2019

*Corresponding author: Department Sharia Economic, Faculty of Economic and Business, Universitas Internasional Semen Indonesia. Kompleks PT. Semen Indonesia (Persero) Tbk, Jl. Veteran, Kb. Dalem, Sidomoro, Kebomas, Gresik, Indonesia

Email: ahmadhudaifah@uisi.ac.id 
134 Al-Uqud: Journal of Islamic Economics

Volume 3 Issue 2, July 2019

\begin{abstract}
Abstrak
Tujuan dari penelitian ini adalah untuk mempelajari kelayakan pasar, teknis, dan finansial dari proyek crowdfunding menggunakan kontrak Islam pada proyek pertanian. Proses tersebut dilakukan untuk mengidentifikasi kelayakan penggunaan lahan dengan investasi yang dikumpulkan melalui crowdfunding. Metode penelitian dilaksanakan dengan pendekatan kuantitatif untuk menghitung kelayakan finansial. Proyek investasi melibatkan lahan seluas 3,8 hektar yang terletak di Kampus C UISI yang merupakan tanah bekas tambang dari Perusahaan Semen Indonesia. Total investasi dan pendanaan modal mencapai Rp 100.000.000. Periode pengembalian investasi adalah 2 tahun. Berdasarkan perhitungan untung dan rugi, dapat dihitung bahwa modal dan investasi akan kembali pada bulan ke 6 tahun pertama. Pada tahun pertama IRR yang diperoleh adalah 19\%, sedangkan sampai akhir tahun kedua IRR diperoleh sebesar 42\%. Perbedaan signifikan terjadi karena pada tahun kedua Belimbing Tasikmadu, dan buah Jambu Kristal sudah bisa dipanen untuk tujuan komersial.
\end{abstract}

Kata kunci: Lahan Bekas Tambang; Kelayakan Finansial; Internal Rate Of Return; Net Present Value 


\section{INTRODUCTION}

The construction of a project requires analysis to determine the feasibility of the project. The purpose of a project feasibility study is to review whether the project is feasible in several aspects, for example technical aspects, managerial and administrative aspects, organizational aspects, commercial aspects, economic aspects and financial aspects. The feasibility study according to Jumingan (2009: 25 ) is a comprehensive assessment to assess the success of a project. In addition, the purpose of the project feasibility study is to avoid the investment that is too large for activities that turn out to be unprofitable. The project is a unique activity. Therefore, each project requires a different study. However, most of the feasibility studies carried out financial studies to determine the financial projections of a project in the future. The output of this feasibility study is a proposal that contains the feasibility of all aspects to convince investors, usually banks, to invest money to run the project. Financial studies are used by investors to find out whether the investment they spend will be profitable or not.

Based on existing conditions and the existence of market potential and abundant water availability, this study will conduct a feasibility study of campus $\mathrm{C}$ land use to be developed into business land that can provide benefits to investors. Investors targeted for Campus $\mathrm{C}$ land use are the internal environment of the UISI Campus, namely lecturers and academic staff with the crowd funding method. Campus of C UISI is land using of ex-clay mining for productive area such as agriculture sector utilization (farming, plantation, and fishery). Crowdfunding is a financing scheme that is often dubbed as "democratic funding", because the concept of funding is to collect funds on a small scale but come from many people. Crowdfunding is a practice of raising funds for various types of businesses, whether in the form of product ideas, business or activities, whose funds are obtained from many community contributions and often have a reward in the form of goods or services (Young, T.E., 2012). The inspiration for crowdfunding comes from the concept of micro-finance (Morduch, 1999) and crowdsourcing (Poetz, 2012). Types of projects that use crowdfunding methods themselves can be categorized to facilitate classification or differentiate each existing project (Hermer, 2011). 
This concept is suitable to be applied at the UISI Campus because the academic community at the UISI Campus is quite large, reaching 100 people. The investment of funds needed for this land use project is also not too large because the land is already available, land processing equipment is also available, and the land is not too large. Financing is only needed for working capital and little technology investment to optimize land use.

In this study market studies, technical studies, and financial studies will be carried out so that the feasibility of the land use project and the amount of funding needed to carry out this project will be collected with the concept of crowd funding. What agricultural commodities will be planted, quantity, and production time will be the decision variables in this study. In addition, in this study a financing scheme will be determined using the crowd funding model. With this research expected in the future, Campus C's land can be optimally utilized so that it can become one of the business sectors of the Campus UISI.

The study concentrating on the crowdfunding as vehicle for social and economic financing has been drawn attention and interest from researchers. The crowdfunding is a moderate and innovative means of financing pull facilitation the fund owner and project doer. Hitherto, the crowdfunding has mostly been facilitated through online web platform and technological support. To cite and refer some articles and journals, the study lies theoretically on the previous works of Laurell, C. et.al (2018), Kaura H. and Gerab, J. (2017), Li, Haifeng (2018), Forbesa, H. and Schaefera, D. (2017), Ibrahima, N. and Verliyantina (2012), Permaisela D (2019). The successful crowdfunding campaign relies on the several key features such as selecting the right platform, setting up the funding goal and initiating the proper and impressive reward for participants consisting of investor and donator (Forbesa, H. and Schaefera, D. 2017).

The relation between crowdfunding campaign initiative and Islamic economics has been developed to invigorate the social religious donation namely waqf, shodaqoh and zakat. Thaker, M.A. (2016) proposed a waqf fund to finance micro and small enterprises by means of an Integrated Cash Waqf Micro Enterprise Investment (ICWME-I) Model. The proposed scheme utilizes the cash waqf fund 
collected to be a source of flexible and inexpensive fund for micro and small enterprise. The waqf fund can urge and stimulate potential approaches to overcome primary obstacle for micro and small enterprises to grow more profitable and sustainable. The hinderance and deterrent of micro and small enterprise scale up are mainly explained by inadequate collateral, insufficient, legal status, high transaction costs, insufficient information and documentation, no financial track record, the nature and quality of the business, the rigidity of the financing procedure and a lack of awareness of the financial facilities.

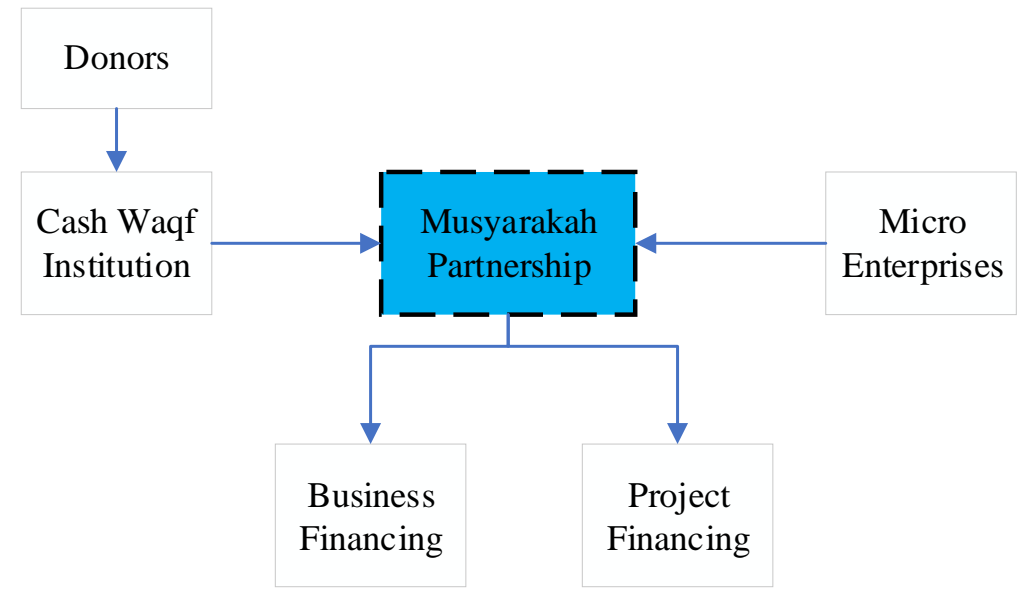

Graph 1. Integrated Cash Waqf Micro Enterprise Investment (ICWME-I) Model Source: Thaker, M.A., 2016

Duasaa, J. and Thaker, M.A (2017) examined and deliberated the concept of Integrated Cash Waqf Micro Enterprise Investment (ICWME-I) Model referring to Malaysian case and experience. The micro and small business operators in Malaysia are presumably regarded unable to access bank financing facility due to various impediments namely tight documentation requirement, lack of collateral commercial costly financing. To solve and tackle such problem, an independent source of financing should be discovered and chosen in replacing commercial financing intermediary for banking system. One of feasible alternatives may come from waqf (social endowment fund) with the high degree of flexibility and usability. The collective social finance is vastly generated through crowdfunding scheme employing several platform vehicles particularly internet technology. The waqf 
manager (custodian) must ensure the perpetuity of waqf value in which the modern best practice prevails cash donation option. The responsibility of waqf manager lies in the fund collection which is directly channeled into waqf beneficiaries or indirectly generated for productive investment and its profits to be allocated for waqf beneficiary program.

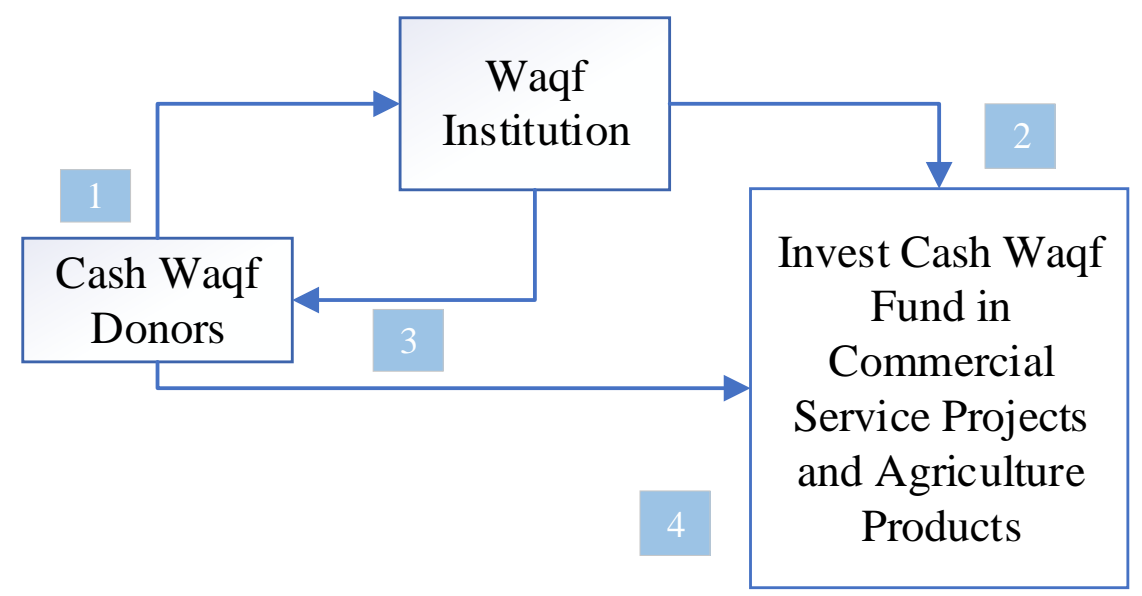

Graph 2. Cooperative-Waqf Model

Source: Pitchay, et.al. (2017)

Pitchay, et.al. (2017) proposed distinct but similar concept how to manage cash waqf model into a collective investment project like crowdfunding entitled Cooperative Waqf Model (CWM). The workability of such proposal relies on the excellent performance of waqf management or crowdfunding custodian in developing and ensuring the profitability and security of investment project. The scheme of CWM involves consecutively four stages benefiting various stakeholders in the collective schemes. Stage 1: donors are expected to contribute cash waqf to the waqf institution via various available methods of payment such as salary deduction. Stage 2: the waqf institution will continue to develop a lucrative project possible within time frame of agreement and fund collected. Stage 3: the waqf institution will release and facilitate membership cards for the donors who have contributed into the project. Stage 4: the benefit and facility of this membership is to furnish and reward a privileged or a discounted rate in accessing any waqf-based commercial services project or purchase any agricultural products. Such privilege 
is to ensure an attachment and bounding between waqf donors, investment managers and stakeholders.

\section{RESEARCH METHODS}

The research was quantitative research. Quantitative research is research by calculating financial feasibility

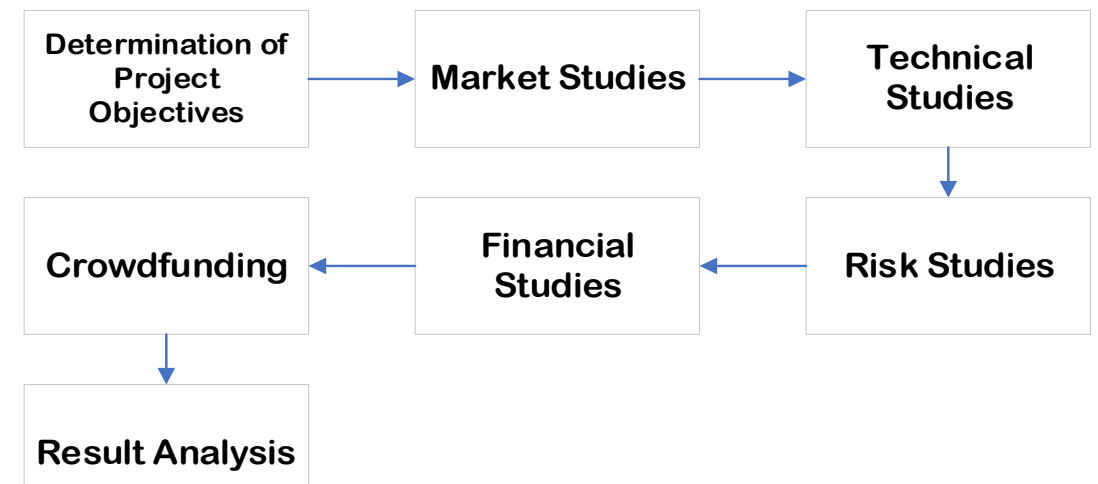

Graph 3. Flow Diagram of Research Implementation Source: Author's Illustrative (2019)

Analysis of economic is the last stage in the design of the factory to determine feasibility of agroindustry factory of black grass jelly powder to be realized: HPP (Production Cost)

Calculation of HPP with using formulaas:

The amount of

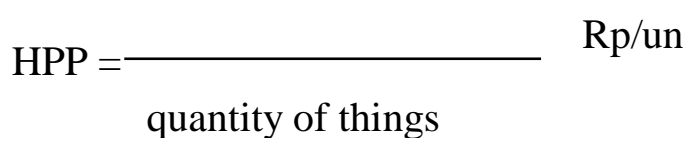

BEP (Break Event Point)

Determining ofBreak Event Point (BEP), mathematicallycan be formulated as:

$$
B E P(\text { unit })=\frac{F C}{P-V C}
$$




$$
B E P(\text { price })=\frac{F C}{1-\left(\frac{V C}{P}\right)}
$$

Note:

$\begin{array}{ll}\mathrm{FC} & : \text { Fixed Cost }(\mathrm{Rp} / \mathrm{th}) \\ \mathrm{VC} & : \text { Variable Cost }(\mathrm{Rp} / \mathrm{unit} ; \mathrm{Rp} / \mathrm{kg}) \\ \mathrm{P} & : \text { Price }(\mathrm{Rp} / \mathrm{kg} ; \mathrm{Rp} / \mathrm{unit})\end{array}$

Fixed costs are total costs that will not change if there is a change in production volume. Total fixed cost will always be constant until the full capacity level. Fixed costs are the costs that will always occur even if the company does not produce. Variable cost is the total cost that varies depending on changes in sales volume / production. Variable costs will change proportionally with changes in production volume.

PP (Payback Period)

General formula with using forcalculatepayback periodas:

$$
P P=\left[t+\frac{b-c}{d-c}\right] \times 12 \text { months }
$$

\section{Work Efficiency}

Analysis of work efficiency withcalculation ofReturn Cost Ratio atau R/C ratio (Soekartawi, 1995). R/C ratioiscomparison betweenTotal Revenue (TR) withTotal Cost (TC). R/C is formulated by:

$$
R / C=\frac{T R}{T C}
$$

$$
\begin{aligned}
& \text { With } \mathrm{TR}=\mathrm{P} \times \mathrm{Q} \\
& \mathrm{TC}=\mathrm{TFC}+\mathrm{TVC}
\end{aligned}
$$

Where:

$\mathrm{TR}=$ Total Revenue $(\mathrm{Rp})$

$\mathrm{P}=$ Price $(\mathrm{Rp})$

$\mathrm{Q}=$ Quantity (unit)

$\mathrm{TC}=$ Total Cost $(\mathrm{Rp})$

These criteria of evaluation with using $\mathrm{R} / \mathrm{C}$ ratioare :

$\mathrm{R} / \mathrm{C}<1$ : unefficient 
$\mathrm{R} / \mathrm{C}=1:$ netral

$\mathrm{R} / \mathrm{C}>1$ : efficient and feasible

\section{RESULTS AND DISCUSSION \\ Investment Contract}

The contract (investment contract) implementation of Campus C UISI investment was carried out with a mudharaba scheme called the Mudharabah AgriCrowdfunding. Basically, the cooperation contract considers proportionally directly involved parties consisting of fund owners (investors), managers (investment managers), land owners and cultivators. Especially for cultivators, labor salaries will be considered as costs that reduce income. Shareholders of cultivators are bonuses from planting activities that can produce ducks.

\section{Spatial Design Development Planning for Campus C UISI}

At present, the ex-mining area becomes Campus C UISI where the designation is a live laboratory and as a green land. Management of Campus $\mathrm{C}$ green land under the responsibility of the UISI Green Campus Team. Campus C UISI has several plots of land for planting areas, green houses, 2 classrooms, 1 production lab, warehouse for equipment storage, pendopo (mushola).

Commodities Plants that are easily sold at high prices and the risk of low planting failure. Income potential reaches about 4 times the investment cost. Financial risk, namely the possibility that the company cannot fulfill its financial obligations. This level of risk is influenced by estimates of cash flows to be received by the company and financial obligations that are permanent (Gitman, 2003).

Affordable investment value with packages starting at 1 million. Estimated profit sharing reaches 160 percent for 9 months / 18 percent per month (calculation of business feasibility studies). Invest by preserving the natural environment. Clifton (1977) states that the purpose of market studies is to estimate the amount of market demand for products to be sold in the future. The trend of public acceptance both in product type, quality, packaging, distribution channel location, and product prices. 
Campus $\mathrm{C}$ has an area of 3.8 ha which is used for mining limestone and clay for cement production. Currently the land is used for planting areas of several commodities including Sweet Corn, California Papaya, Guava, Soursop, Melon, Watermelon, Cantaloupe, Dragon Fruit, Banana, Chili, Red Chilli, Tomatoes, and several vegetables (mustard, spinach red, kale). Land using is not optimal because of the lack of human resources (4 field workers). UISI's internal funding sources are also very limited, even though it has great potential to be developed commercially and profitably. The low level of productivity of the plant causes the product cannot be sold to the market at large. During this time the majority of sales were made in the UISI and Foundation market segments. Some products are sold to employees of PT. Semen Indonesia, Tbk and several community groups near Campus C. Based on the problems, we created crowdfunding simulation. Crowdfunding is a practice of raising funds for various types of businesses, whether in the form of product ideas, business, or activities, whose funds are obtained from many community contributions, and often have a reward in the form of goods or services (Young, T.E., 2012).

\section{Analysis of Needs and Revenues Potential}

Total Investment and Capital Requirements of Rp 100,000,000. The investment return period is 2 years. The return on investment is $40 \%$ after 2 years. Investment needs will be sold in the form of shares per slot price of Rp1,000,000. Per person may purchase a maximum of 5 stock slots. Distribution of results is based on the proportion of shares given.

Commodities chosen to be planted on ex-mine land have high selling points and high levels of market demand and are relatively stable. Belimbing Tasik Madu has a high selling value, which is IDR $15,000 / \mathrm{kg}$. This plant can be harvested after a 1-year planting period and can be harvested every 4 months. Each tree can produce $40 \mathrm{~kg}$ per harvest. Other commodities that have high selling value are Jambu Kristal with a selling price of Rp. 18,000 / kg. Jambu Kristal can be harvested after a 1.5-year planting period and harvested every 3 months. Each tree can produce $10 \mathrm{~kg}$ per harvest. In addition to Jambu Kristal and Belimbing Tasik Madu, 
another commodity planted is Butternut Squash. This unique shaped fruit has many devotees, one of whom is young mothers. In the present, people have begun to care about health. One of them is young mothers who need breastmilk substitutes (mpasi) to meet their nutritional needs. One choice of food ingredients is butternut squash. The unique shape also becomes the main attraction for buyers. The selling price of Butternut Squash is around Rp. $18,000 / \mathrm{kg}$. This fruit has a relatively fast planting cycle, which is around 3 months. 1 Butternut Squash plant produces $10 \mathrm{~kg}$ of fruit.

Other commodities planted are seasonal crops, such as vegetables (Chili, Eggplant, and Tomatoes); Golden Melon fruit; and Corn. Uwi and Gembili are also grown to become intercrops. This annual plant is a plant that is a daily necessity for the community. The marketing strategy undertaken is to open a stall to market exmine land yields. The stalls will be opened in containers (currently 3 containers are available). Unique container design and good quality of harvest can be one of the more selling points for ex-mine land yields. In addition to selling crops in container stalls, fruit will also be marketed in modern retail stores.

\section{Financial Feasibility Analysis}

Currently ex-mining land has been planted with several commodities. The investment that has been held on ex-mining land is used for land management, so that the investment needs of the equipment can be minimized. The investment needs to be carried out are the procurement of compost houses and container repairs for the Ngipik market. In addition, what needs to be done is processing the land and procuring fertilizers, pests and seeds. Operational needs are divided into several parts, namely Land Management, Production (Seeds, Pest Drugs, and Fertilizers), Plant Care, and Labor. Details of the cost requirements will be explained in the Financial Study Sub-Chapter. 


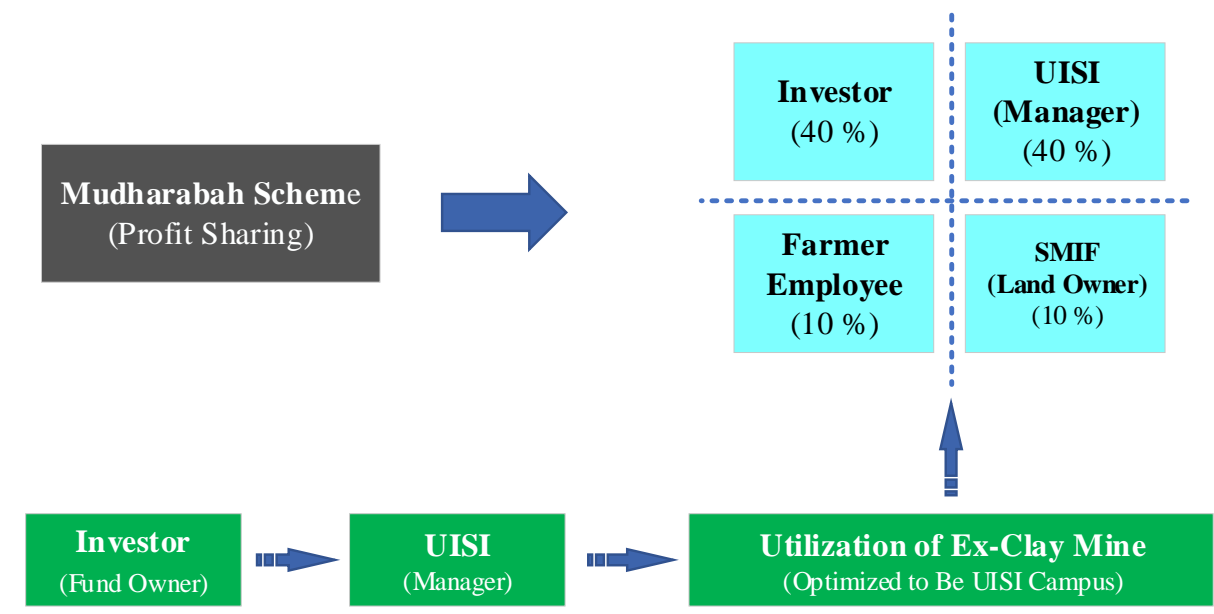

Graph 4. Mudharobah Agri Crowdfunding Scheme Source: Author's Illustrative (2019)

Based on the investment and working capital requirements described in the Technical Review and Market Potential Sub-Chapters described in the Market Study Sub-Chapter, this chapter will explain financial studies to determine the feasibility of ex-mining land development projects.

The calculation is done with a projection time of 2 years. Each commodity has a 3-6-month harvest cycle. However, the Belimbing Tasik Madu plant can only be harvested after 1.5 years after planting, and Jambu Kristal can be harvested after 1 year of planting. Based on the results of the calculations (details in the appendix) a cash flow statement is obtained in Table 1.

Table 1. Report of Projection Cash Flow for 2 Years

\begin{tabular}{|c|c|c|c|c|c|c|c|}
\hline \multirow{2}{*}{ Components } & \multicolumn{7}{|c|}{$1^{\text {st }}$ Year } \\
\hline & $0^{\text {th }}$ & $3^{\text {rd }}$ & $4^{\text {th }}$ & $6^{\text {th }}$ & $8^{\text {th }}$ & $9^{\text {th }}$ & $12^{\text {th }}$ \\
\hline Costs & 117.888 .000 & 12.138 .000 & 13.200 .000 & 32.888 .000 & 11.700 .000 & 13.608 .000 & 45.088 .000 \\
\hline Land & & & & & & & \\
\hline Management & 4.000 .000 & 2.000 .000 & 2.000 .000 & 3.000 .000 & 3.000 .000 & 3.000 .000 & 4.000 .000 \\
\hline Production & 31.388 .000 & 5.838 .000 & 6.300 .000 & 9.088 .000 & 3.800 .000 & 5.408 .000 & 17.388 .000 \\
\hline Labors & 17.500 .000 & 4.000 .000 & 4.900 .000 & 5.500 .000 & 4.900 .000 & 4.900 .000 & 8.400 .000 \\
\hline Supporting & 65.000 .000 & - & - & 15.000 .000 & - & - & 15.000 .000 \\
\hline Maintenance & - & 300.000 & - & 300.000 & - & 300.000 & 300.000 \\
\hline $\begin{array}{l}\text { Income } \\
\text { Harvesting }\end{array}$ & & 7.800 .000 & 62.400 .000 & 79.800 .000 & 62.400 .000 & 67.800 .000 & 81.800 .000 \\
\hline
\end{tabular}

Source: Data Processed, 2018 
Bambang Tutuko, Ahmad Hudaifah, M. Asyhad, Paramita Setyaningrum, Irvan

Adhin Cholilie: Mudharabah Agri-Crowdfunding In The Ex-Clay Mine

Utilization Program of PT. Semen Indonesia (Persero), Tbk. Campus of C

Universitas Internasional Semen Indonesia

Table 2. Report of Projection Cash Flow for 2 Years (Continued)

\begin{tabular}{|c|c|c|c|c|c|c|c|c|c|}
\hline \multirow{2}{*}{ Components } & \multicolumn{9}{|c|}{$2^{\text {nd }}$ Year } \\
\hline & \multicolumn{3}{|c|}{$3^{\text {rd }}$} & \multicolumn{2}{|c|}{$4^{\text {th }}$} & $6^{\text {th }}$ & $8^{\text {th }}$ & $9^{\text {th }}$ & $12^{\text {th }}$ \\
\hline & \multicolumn{2}{|c|}{13.338 .000} & \multicolumn{2}{|c|}{13.200 .000} & 32.888 .000 & 11.700 .000 & 13.608 .000 & 46.288 .000 \\
\hline Land & & & & & & \multirow{2}{*}{3.000 .000} & \multirow{2}{*}{3.000 .000} & & \\
\hline Management & & \multicolumn{2}{|c|}{2.000 .000} & \multicolumn{2}{|c|}{2.000 .000} & & & 3.000 .000 & 4.000 .000 \\
\hline Production & & \multicolumn{2}{|c|}{5.838 .000} & \multicolumn{2}{|c|}{6.300 .000} & 9.088 .000 & 3.800 .000 & 5.408 .000 & 17.388 .000 \\
\hline Labors & & \multicolumn{2}{|c|}{5.200 .000} & \multicolumn{2}{|c|}{4.900 .000} & 5.500 .000 & 4.900 .000 & 4.900 .000 & 9.600 .000 \\
\hline Supporting & & \multicolumn{2}{|l|}{-} & \multicolumn{2}{|c|}{-} & 15.000 .000 & - & - & 15.000 .000 \\
\hline Maintenance & & \multicolumn{2}{|c|}{300.000} & \multicolumn{2}{|c|}{-} & 300.000 & - & 300.000 & 300.000 \\
\hline $\begin{array}{l}\text { Income } \\
\text { Harvesting }\end{array}$ & & \multicolumn{2}{|c|}{82.200 .000} & \multicolumn{2}{|c|}{62.400 .000} & 127.800 .000 & 76.800 .000 & 115.800 .000 & 144.200 .000 \\
\hline Sourc & e: $\mathrm{D}$ & Process & ec & $18 \mathrm{Tal}$ & le 3. Repor & rt of Profit and & 1 Loss & & \\
\hline Co & & & & & & $1^{\text {st }}$ Year & & & \\
\hline & & $0^{\text {th }}$ & & rd & $4^{\text {th }}$ & $6^{\text {th }}$ & $8^{\text {th }}$ & $9^{\text {th }}$ & $12^{\text {th }}$ \\
\hline Profit/ Loss & 117 & 888.000 & 55. & 52.000 & 49.200 .00 & $00 \quad 46.912 .000$ & $0 \quad 50.700 .000$ & 54.192 .000 & 36.712 .000 \\
\hline Net & 117 & 888.000 & 62. & 26.000 & 13.026 .00 & $00 \quad 33.886 .000$ & $0 \quad 84.586 .000$ & 138.778 .000 & 175.490 .000 \\
\hline Comnone & & & & & & & Year & & \\
\hline & & & $3^{\text {rd }}$ & & $4^{\text {th }}$ & $6^{\text {th }}$ & $8^{\text {th }}$ & $9^{\text {th }}$ & $12^{\text {th }}$ \\
\hline Profit/ Loss & & 68. & 362.0 & 49. & 200.000 & 94.912 .000 & 65.100 .000 & 102.192 .000 & 97.912 .000 \\
\hline Net & & 244 & 352. & & .552 .000 & 388.464 .000 & 453.564 .000 & 555.756 .000 & 653.668 .000 \\
\hline
\end{tabular}

Source: Data Processed, 2018

Based on the Profit and Loss Report, capital and investment will return in the 6th month of the 1 st year. In the 1st year the IRR obtained was $19 \%$, whereas until the end of the second year the IRR was obtained at $42 \%$. A significant difference occurs because in the second year Blimbing Tasik Madu and Jambu Kristal fruit can be harvested. Based on the financial feasibility study, the ex-mine land development project is declared feasible because of the high IRR value and fast payback period (less than one year).

The risk that might arise from this ex-land mine development project is crop failure. This has been anticipated in technical studies by adding labor to periodically 
control plant conditions. In addition, the crop yields a failure of $20 \%$ of the optimal yield.

\section{CONCLUSIONS}

The implementation of the investment contract (contract) of UISI C Campus was carried out with a mudharabah (profit and loss sharing scheme/contract) called Mudharabah Agri-Crowdfunding. Currently the ex-mining land becomes Campus C UISI where the designation is a live laboratory and as a green land. sold at high prices and the risk of low planting failure. The campus $\mathrm{C}$ has an area of 3.8 ha which is used for mining limestone and clay for cement production.

Total Investment and Capital Requirements of Rp 100,000,000. The return period of investment is 2 years. The commodities chosen to be planted on ex-mining land have high selling values and high and relatively stable market demand. Other commodities that have high selling value are Jambu Kristal with selling prices reaching Rp. 18,000 / kg. Other commodities planted are seasonal crops, such as vegetables (Chili, Eggplant, and Tomatoes); Golden Melon fruit; and Corn. Uwi and Gembili are also grown to become intercrops. This annual plant is a plant that is a daily necessity for the community.

Currently ex-mining land has been planted with several commodities. However, the management is not optimal. The investment needs to be carried out are the procurement of compost houses and container repairs for the Ngipik market. Based on the Profit and Loss Report, capital and investment will return in the 6th year of the year. In the 1st year the IRR obtained was 19\%, whereas until the end of the second year the IRR was obtained at $42 \%$. A significant difference occurs because in the second year Belimbing Tasik Madu and Jambu Kristal fruit can be harvested. Based on the financial feasibility study, the ex-mine land development project is declared feasible because of the high IRR value and fast payback period (less than one year). 


\section{REFERENCES}

Clifton, D. S., \& Fyffe, D. E. 1977. Project Feasibility Analysis: A Guide to Profitable Ventures. (St Louis, MO, U.S.A.): John Wiley \& Sons Inc.

Duasaa, J. and Thaker, M.A, 2017, Proposed Integrated Cash Waqf Investment Model for Micro Enterprises in Malaysia: An Empirical Analysis, Journal of Islamic Philanthropy \& Social Finance; Vol.1, No.2; 2017 eISSN: 25903942, Published by Center for Islamic Philanthropy \& Social Finance

Forbesa, H. and Schaefera, D., 2017, Guidelines for Successful Crowdfunding, 27th CIRP Design 2017, Procedia CIRP 60 (2017) 398 - 403, http://doi.org/10.1016/j.procir.2017.02.021

Gitman, Lawrence J. 2003. Principles of Managerial Finance, $10^{\text {th }}$ ed., International Editions Financial Series. Boston: Addison-Wesley.

Hemer, J. 2011. A Snapshot on Crowdfunding. Working Papers Firms and Region, $\mathrm{R} 2$.

Ibrahima, N. and Verliyantina, 2012, The Model of Crowdfunding to Support Small and Micro Businesses in Indonesia Through a Web-based platform, International Conference on Small and Medium Enterprises Development with a Theme "Innovation and Sustainability in SME Development" (ICSMED 2012), http://doi.org/10.1016/S2212-5671(12)00353-X

Jumingan. 2009. Studi Kelayakan Bisnis. Bumi Kasara. Jakarta.

Kaura H. and Gerab, J., 2017, Effect of Social Media Connectivity on Success of Crowdfunding Campaigns, Information Technology and Quantitative Management (ITQM2017), Procedia Computer Science 122 (2017) 767-774

Laurella C., Sandströmb C., Suseno, S., 2018. Assessing the Interplay Between Crowdfunding and Sustainability in Social Media, Technological Forecasting \& Social Change, https://doi.org/10.1016/j.techfore.2018.07.015

Li, Haifeng, Chen, X., Zhang Y., Hai, M., 2018, Empirical Analysis of Factors on Crowdfunding with Trust Theory, The International Academy of Information Technology and Quantitative Management, the Peter Kiewit Institute, University of Nebraska, Procedia Computer Science 139 (2018) 120-126, https://doi.org/10.1016/j.procs.2018.10.227

Morduch, J. 1999. The Microfinance Promise. Journal of Economics Literature 37, 1569. 
Permaisela, D., 2019, Analysis of Productive Waqf Practice And Management: Using SWOT Analysis Method, Al-Uqud: Journal of Islamic Economics, Volume 3 Number 1, January 2019 E-ISSN 2548-3544, P-ISSN 2549-0850 Halaman 85-97 http://doi:10.26740/al-uqud.v3n1.p85-97

Pitchay, A.A., Thaker, M.A., Mydin. A., Azhar, A., and Latiff, A. R., 2017, Cooperative-Waqf Model: A Proposal to Develop Idle Waqf Lands in Malaysia, ISRA International Journal of Islamic Finance, Vol. 10 Issue: 2, pp.225-236, https://doi.org/10.1108/IJIF-07-2017-0012

Poetz, M., \&Schreirer, M. 2012. The Value of Crowdsourcing: Can Users Really Compete with Professionals in Generating New Product Ideas? Journal of Product Innovation Management.

Pujawan, I. N. 2008. Ekonomi Teknik (Edisi Kedua). Surabaya. Penerbit Guna Widya.

Thaker, M.A., Mohammed, M.O., Duasa J. and Abdullah M.A., 2016, The Behavioral Intention of Micro Enterprises to Use the Integrated Cash Waqf Micro Enterprise Investment (ICWME-I) Model as a Source of Financing, Gadjah Mada International Journal of Business Vol. 18, No. 2 (May-August 2016):

$111-130$

Young, T. E. 2012. The Everything Guide to Crowdfunding: Learn How to Use Social Media for Small-Busi 